\title{
Recent Studies in the Use of Propolis as a Traditional Medicine: A Review
}

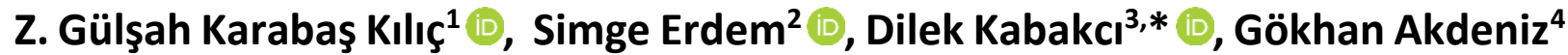

\author{
${ }^{1}$ Hocalar State Hospital, Family Physician, Afyon, Turkey \\ ${ }^{2}$ Ordu State Hospital, Hematology, Ordu, Turkey \\ ${ }^{3}$ Muş Alparslan University, Faculty of Applied Sciences, Muş, Turkey \\ ${ }^{4}$ Apiculture Research Institute, Ordu, Turkey
}

\section{Article History \\ Received 31 May 2020 \\ Accepted 10 July 2020}

First Online 31 July 2020

\section{*Corresponding Author \\ Tel.: +905309634668 \\ E-mail: dilek_kabakci@hotmail.com}

\section{Keywords}

Apiculture

Honey bee

Apicultural products

Propolis

\begin{abstract}
Propolis is formed by honey bees through mixing a quantity of wax into the resinous substances, which they create by mixing the plant secretions in the pollen baskets on their hind legs with enzymes in their saliva. Depending on the source from which it is obtained, propolis is found in a wide variety of colours, such as yellow, green, dark brown, being solid-state at room temperature. For centuries, apicultural products (such as honey, pollen, propolis, bee venom, bee bread and royal jelly) have been used in traditional medicine for treatment purposes. In recent years, biochemical studies related to propolis have focused on the antimicrobial, anti-inflammatory, antitumoral, and antioxidant activities of propolis.
\end{abstract}

\section{Introduction}

Honey is the most known product among honey bee products. However, other products such as pollen, royal jelly, wax, propolis and bee venom, which are of great economic and ecological importance, also play an important role in human, is also used as food and they are used as food supplements in the treatment of many diseases (Kaftanoğlu, Kumova, \& Yeninar, 1992; Kumova, 2001). Any use of these bee products for human health is called apitherapy, and this method forms an important part of traditional and complementary medicine (Stangaciu, 2006; Şirin, Çakırı, Can, Yıldız, \& Kolaylı, 2016; Zumla \& Lulat, 1989). Propolis is produced by honey bees using plant resins (Bankova, Castro, \& Marcucci 2000; Silici, 2019). In addition to being considered as a substance produced by honeybees to protect their hives (filling the gaps, preventing the cracking of the hive, making the inner surface of the hive smooth), propolis has also been reported to have antiseptic properties that protect larvae and honeycombs against microbial infections. Covering the inside of the hive with propolis, the infection carried by honey bees, in close contact with each other, is prevented from spreading within the hive by Kuropatnicki, Szliszka, and Krol (2013). In short, propolis is used for many purposes such as protecting the honey bee colony from diseases and microbial infections, providing a hygienic habitat by covering hive walls and larval cells, and shrinking the hive entrance hole (Silici, 2019). Although the composition of raw propolis varies depending on its source, it is generally composed of $50 \%$ resin, $30 \%$ wax, $10 \%$ essential and aromatic oils, $5 \%$ pollen, and $5 \%$ other organic compounds and mineral substances (Doğan \& Hayaoğlu, 2012). There are many studies on the content of 
propolis in the world and in our country. In a study conducted by (Silici, 2008), biological components of propolis samples belonging to poplar, Castanea sativa, Eucalyptus globulus and Eucalyptus with different botanical origins were analyzed with gas chromatography-mass spectrometry (GC-MS) and compared. The dominant compounds identified in the study were phenolic compounds, organic acids and fatty acids, and their esters, hydrocarbons, quinones, amines, alcohol, and terpenes. The difference between the analyzed chemical parameters was found statistically significant $(P<0.05,0.01)$. It was reported that the total amount of phenolic matter varied between 87.62$127.39 \mathrm{mg}$ GAE (Gallic acid equivalents) propolis. Karlıdağ and Genç (2007) investigated the amount of resin containing biologically active agents in propolis samples produced by different methods from Caucasian, Carniolan, and Anatolian subspecies honeybees. It was determined that the resin content of propolis samples obtained in the study ranged between $11.40-67.79 \%$ and that the difference between the resin content of propolis samples in different treatment groups was statistically significant $(P<0.05)$. Gençay and Salih (2009) compared the organic compound content of propolis samples obtained from different regions of Turkey, Brazil and Japan. As a result of the study, it was reported that the flavanone and flavonol content of Turkey propolis was higher compared to samples collected from Brazil and Japan. In the study in which they determined the chemical content of 64 propolis samples obtained from the districts of Hakkari province (Center, Çukurca, Yüksekova, and Şemdinli) by using GSMS. Bayram, Sorkun, Cevahir Öz, Salih, and Topçu (2018) found that samples of Şemdinli contained a higher amount of flavonoids. 27 types of coumarin were identified in 28 of these 64 propolis samples, and it was reported that propolis samples belonging to Yüksekova were richer in coumarin ratio compared to others.

Propolis has been used in traditional medicine for treatment purposes. However, the interest in propolis has increased across the world recently, and by conducting studies related to the chemical composition and biological properties of propolis, it has been explicitly shown that propolis has antimicrobial, antiinflammatory, antitumoral, antioxidant and immunomodulatory activities (Bogdanov, 2016; Cora, 2018). In this review, data regarding studies using propolis as a traditional medicine in the treatment of some diseases are discussed.

\section{Studies Conducted Using Propolis}

Since ancient times, the positive effects of propolis on human health has been known (Çelemli, \& Özkırım, 2011). In the research conducted by El Adaouia Taleb, Djebli, Chenini, Şahin, and Kolaylı (2020), to determine the antidiabetic effect of propolis on rats, four groups of five rats each were formed. In the study, $0.5 \mathrm{~mL} / 100 \mathrm{~g}$ doses of $30 \%$ and $15 \%$ propolis extacts were given to diabetic rats for 4 weeks. As a result of the study, it was reported that glucose values for propolis administered groups decreased from $393 \pm 192.7$ to $154 \pm 28.0 \mathrm{mg} / \mathrm{dL}$ and from $386 \pm 141.1$ to $331.5 \pm 123.74 \mathrm{mg} / \mathrm{dL}$. In the study, it was also demonstrated that the glucose value was significantly reduced in the $30 \%$ propolis administered group and that propolis was a remarkable product with clinical effect in the treatment of diabetes.

Hosseini et al. (2020) aimed to investigate the inhibition effects of propolis on the growth of the Aspergillus parasiticus fungal species, the production of aflatoxin classified as a group I carcinogenic compound by the International Agency for Research on Cancer, and the expression of aflatoxin biosynthesis pathway genes. In the study, the minimum inhibitory concentration (MIC) value was determined to be $100 \mu \mathrm{g} / \mathrm{mL}$ after the test was carried out. It was also stated that by $50 \mu \mathrm{g} / \mathrm{mL}$ of propolis treatment, the total level of aflatoxin decreased from $386.1 \mathrm{ppm}$ to $3.01 \mathrm{ppm}$. After the treatment performed with propolis extract, a significant reduction in the expression level of the nor -1 , ver -1 , and omtA genes in the aflatoxin biosynthesis pathway was reported that propolis extract has inhibitory properties.

Afsharpourac, Javadiab, Hashemipourc, Koushand, and Haghighiana (2019) evaluated the effect of the propolis support on blood sugar, insulin resistance, and antioxidant status in Type 2 diabetes. In this study, sixtytwo patients with Type 2 diabetes (aged 30-55) were randomly divided into two groups, propolis and placebo $(n=31)$. Patients were given propolis or placebo three times a day (500 mg each time and a total of $1500 \mathrm{mg}$ ). At the beginning and the end of the study, fasting blood glucose (FBG), two-hour postprandial glucose (2-hp), insulin, insulin resistance (IR), hemoglobin A1c (HbA1c), total antioxidant capacity (TAC), glutathione peroxidase (GPx) and superoxide dismutase (SOD) activity values were measured. Measurements carried out after two weeks showed that the levels of FBG, 2-hp, insulin, IR, and $\mathrm{HbA1C}$ significantly decreased in the group of patients given propolis supplements compared to those given placebo. Additionally, it was found that propolis supplementation significantly increased TAC levels in the blood and GPx and SOD activity. As a result of this study, glycemic status, decreases insulin resistance and improves the antioxidant status and, therefore it may be useful as a dietary supplement in patients with Type 2 diabetes.

Karayel (2019) investigated the effects of propolis administration on oxidative stress parameters and acetylcholinesterase activity in brain tissue in rats whose epilepsy model had been generated. A total number of 35 rats were used in the study, divided into 5 groups (G1-G5) with 7 individuals each (G1-control; G2Pentylenetetrazol (PTZ), G3-propolis, G4-PTZ + propolis, G5-PTZ + valproic acid). Seizure detection, seizure scores and total seizure duration were monitored in the study. After the administration, acetylcholinesterase enzyme activity in the brain tissue of rats was evaluated. In 
addition, as indicators of oxidative stress, total antioxidant capacity (TAC) and total oxidant status (TOS) levels were examined. As a result of the study, it was seen that compared to other groups, TAC levels in propolis groups increased significantly and TOS levels decreased, and it was found that the propolis extract reduced oxidative stress and behavioural symptoms of epilepsy.

In another study conducted on propolis samples obtained different regions of Turkey. It was revealed that propolis samples had inhibitory potentials on clinically important enzymes such as urease, xanthine oxidase and acetylcholinesterase. It is emphasized that these inhibition effects detected are due to the phenolic content of the propolis samples that vary depending on the floral origin (Baltaş, Yıldız, \& Kolaylı, 2016).

Ebeid, Abd El Moneim, Benhawy, Hussain, and Hussain (2016) conducted a study to evaluate the radioprotective effect of propolis support in breast cancer patients undergoing radiotherapy. In this study, 135 subjects were divided into 3 groups the first group was control group consisting of healthy women (they were selected in a way to match with the women in the patient group in terms of age and menopausal status), the second group consisted of breast cancer patients taking chemotherapy, and then, undergoing only the radiotherapy and the third group consisted of patients taking radiotherapy and propolis supplements after the chemotherapy. In the patient group supplemented by propolis + radiotherapy, it was concluded that propolis had the ability to significantly reduce radiation-induced DNA damage. In relation to serum iron and hematologic parameters such as hemoglobin concentration, white blood cells, and platelet counts, it was observed that only in patients receiving radiotherapy treatment, these values significantly decreased. However, in patients who were given propolis supplements in addition to radiotherapy, these parameters increased significantly and reached normal control levels.

Because propolis-based preparations had a wide range of applications in various specialities of dentistry, AkhavanKarbassi, Yazdi, Ahadin, and Sadrabad (2016) conducted a study to test the effectiveness of propolis as a mouthwash in reducing oral mucositis that developed due to chemotherapy in a single center. For this purpose, 40 patients with oral mucositis who underwent chemotherapy were divided into 2 groups, and mouthwash with propolis was applied to the 1st group, while mouthwash with water was applied to the 2nd group. In the propolis group, significant differences were observed in oral mucositis, wound, and erythema compared to the placebo group; however, no significant difference was observed in the ability to eat and drink. Furthermore, on the 7 th day of the study, $65 \%$ of the patients in the propolis group were reported to have fully recovered and no significant side effects were observed in the patients.

Ma et al. (2016) examined the advantages of the use of caffeic acid phenethyl ester (CAPE), which is an active antioxidant component derived from propolis, in the treatment of asthma and their role in the regulation of airway micro-environments. It was concluded that CAPE therapy reduced airway hypersensitivity and intense inflammatory cell infiltration in ovalbuminsensitized rats, and inhibited goblet cell hyperplasia, collagen accumulation, and fibrosis. When all the findings obtained from the study were evaluated together, it was revealed that by balancing the airway micro-environment, which emphasizes a new CAPE profile as a powerful agent for asthma management, CAPE alleviates remodelling in the airway inflammation and chronic asthma.

Basma, Ghonome, Hodeib, and Elbadawy (2015), divided the 40 patients between the ages 13-14, who had facial acne, into two groups and applied propolis extract as a local solution to one group and ethanol local solution to the other group. As a result of the research, it has been reported that the local solution of propolis ethanol extract is clinically effective in the treatment of acne vulgaris.

Olczyk et al. (2014) investigated the effect of propolis on the healing of burn wounds. They reported that in burn wounds occurring on pig skins, by reducing the level of fibronectin, propolis reduced the keloid formation, one of the complications that can occur during the burn healing process.

In a research investigating the effect of propolis on the recovery of diabetic foot ulcers (DFU) in humans, Henshaw et al. (2014) administered propolis locally to 24 patients with diabetic foot ulcers at every clinical examination for 6 weeks. As a result of the research, it was reported that propolis had a curative effect and can improve diabetic foot ulcer recovery with weekly administrations.

In another study, Elshon, Muagam, Sadik, and Walaa (2012) examined the antimicrobial activity of propolis extract the upper respiratory tract infections (URTIs) infections in pediatric patients in Yemen. They tested the efficacy of propolis as a treatment for URTIs infections in 41 pediatric patients and observed that a mixture of propolis and goat's milk increased the antimicrobial effect. Complete remission of both streptococcal and candidal symptoms was achieved in all children within a time period less than the recovery time achieved by using each agent alone (2-5 days). Thus, propolis mixed with goat's milk was reported to be a very effective antimicrobial agent for the treatment and management of throat infections caused by bacterial and candidal species in children.

In the study of Çetin et al. (2011), the protection feature of propolis was investigated for liver damage occurring due to methotrexate (MTK) in rats. In the study, 48 rats were divided into four groups. Distilled water + MTK was given to the first group, propolis + MTK to the second group, propolis + isotonic water to the third group, and finally only distilled water + isotonic water to the control group. In liver homogenate samples, malondialdehyde (MDA) concentration, 
superoxide dismutase (SOD), glutathione peroxidase (GSH-Px), and catalase (CAT) activity levels were investigated. In the study, MDA levels were increased and SOD, GSH-px and CAT levels were significantly decreased in the group given MTK. In contrast, it was observed that the MDA level decreased and GSH-Px levels increased in the group administered propolis and MTK, and oxidative stress caused by MTK decreased with propolis administration.

\section{Conclusion}

Propolis is a bee product that is collected from different plant sources by honey bees (Apis mellifera L.), containing densely resin and wax. Propolis has been used in many fields in traditional medicine since ancient times. Propolis, a proven natural bee product, is used in the form of oral intake, topical application (lozenge, mouthwash, cream) in many diseases such as oral mucositis, diabetes mellitus, herpes virus infection, candida infection, gastrointestinal cancers, upper respiratory tract infection, acute bronchitis, ulcer, gastritis, ulcerative coli. Today, studies on propolis are increasing day by day.

\section{References}

Afsharpourac, F., Javadiab, M., Hashemipourc, S., Koushand, Y., \& Haghighiana, H.K. (2019). Propolis supplementation improves glycemic and antioxidant status in patients with type 2 diabetes: A randomized, double-blind, placebocontrolled study. Complementary Therapies in Medicine, 43, 283-288.

AkhavanKarbassi, M.H., Yazdi, M.F., Ahadin, H., \& Sadrabad, M.J. (2016). Randomized double blind placebo controlled trial of propolis for oral mucositis in patients receiving chemotherapy for head and neck cancer. The Asian Pacific Journal of Cancer Prevention, 17(7), 36113614.

Baltas, N., Yildiz, O., \& Kolayli, S. (2016). Inhibition properties of propolis extracts to some clinically important enzymes. Journal of Enzyme Inhibition and Medicinal Chemistry, 31(1), 52-55.

Basma, M.M.A., Ghoname, F.N., Hodeib, A.A., \& Elbadawy, M.A. (2015). Significance of topical propolis in the treatment of facial acne vulgaris. The Egyptian Journal of Dermotology and Venereology, 35(1), 29-36.

Bogdanov, S. (2016). Propolis: biological properties and medical applications. Retrieved from https://www.researchgate.net/profile/Stefan_Bogdano v/publication/304012147

Bankova, V.S., De Castro, S.L., \& Marcucci, M.C. (2000). Propolis: recent advances in chemistry and plant origin. Apidologie, 31, 3-15.

Bayram, N.E., Sorkun, K., Cevahir Öz, G., Salih, B., \& Topçu, G. (2018). Chemical characterization of 64 propolis samples from Hakkari, Turkey. Records of Natural Products, 12(6), 569-581.

Cora, M. (2018). Determination of Antiviral Effects of Some Eastern Black Sea Propolis Samples Against Herpes Simplex Virus Type 1 (PhD Thesis). Karadeniz Technical University Graduate School of Health Sciences, Trabzon,
Turkey.

Çelemli, G. Ö., \& Özkırım, A. (2011). Bal Arılarından Gelen Sağlık Propolis. Bilim Teknik Dergisi, 526, 28-30.

Çetin, A., Kaynar, L., Eser, B., Karadağ, C., Saraymen, B., Öztürk, A., Koçyiğit, ì., Hacıoğlu Kabukçu, S., Çiçek, B., \& Silici, S. (2011). Beneficial effects of propolis on methotrexateInduced liver injury in rats. Acta Oncologica Turgica, 44(1), 1-16.

Doğan, N., \& Hayaoğlu, ì. (2012). Propolis ve kullanım alanları. Harran Tarım ve Gıda Bilimleri Dergisi, 16(3), 39-48.

Ebeid, S.A., Abd El Moneim, A.N., El Benhawy S.A., Hussain, N.G., \& Hussain, I.M. (2016). Assessment of the radioprotective effect of propolis in breast cancer patients undergoing radiotherapy. New perspective for an old honey bee product. Journal of Radiation Research and Applied Sciences, 9, 431-440.

El Adaouia Taleb, R., Noureddine, D., Chenini, H., Şahin, H., \& Kolaylı, S. (2020). In vivo and in vitro anti-diabetic activity of ethanolic propolis extract. Journal Food Biochemistry. https://doi.org/10.1111/jfbc.13267

Elshoni, W., Muagam, F., Sadik, Z., \& Walaa, H. (2012). Antimicrobial activity of propolis extract on URT Infections in pediatric patients admitted to al-thowrah hospital, Hodeidah City, Yemen. World Journal of Medical Sciences, 7(3), 172-177.

Gençay, Ö., \& Salih, B. (2009). GC-MS Analysis Of Propolis Samples from 17 Different regions of Turkey, four different regions of Brazil and one from Japan. Mellifera, 9(17), 19-28.

Henshaw, R.F., Bolton, T., Nube, V., Hood, A., Veldhoen, D., Pfrunder, L., Mckew, L.G., Macleod, C., Mclennan, S.V., \& Twigg, S.T. (2014). Topical application of the bee hive protectant propolis is well tolerated and improves human diabetic foot ulcer healing in a prospective feasibility study. Journal of Diabetes and Its Complications, 28, 850-857.

Hosseini, M.H., Pour, S.H., Amani, J., Jabbarzadeh, S., Hosseinabadi, M., \& Mirhosseini, S. (2020). The effect of Propolis on inhibition of Aspergillus parasiticus growth, aflatoxin production and expression of aflatoxin biosynthesis pathway genes. Journal of Environmental Health Science and Engineering, 18, 297-302.

Kaftanoğlu, O., Kumova U., \& Yeninar, H. (1992). Varroa mücadelesinde son gelişmeler. Doğu Anadolu Bölgesi I. Arıcılık Semineri ( pp 127-137). Erzurum, Turkey

Karayel, B. (2019). The investigation of the effect of propolis on the acetylcholinesterase and oxidative stress in the brain of mouse model of experimental epilepsy model (MSc Thesis). Van Yüzüncü Yıl University, Institute of Health Sciences, Van, Turkey.

Karlıdağ, S., \& Genç, F. (2007). Farkli balarısı (Apis mellifera) Irk ve yöntemleri ile üretilen propolis örneklerinin reçine miktarları. Uludağ Arıcılık Dergisi, 2(1), 52-58.

Kumova, U. (2001). Varroa jacobsoni kontrolünde ülkemizde kullanılan bazı ilaçların etkinliğinin araştırılması. Turkish Journal of Veterinary and Animal Sciences, 25, 597-602.

Kuropatnicki, A. K., Szliszka, E., \& Krol, W. (2013). Historical aspects of propolis research in modern times. EvidenceBased Complementary and Alternative Medicine, 2013, 1-11.

Ma, Y., Zhang, J. X., Liu, Y. N., Gu, H., Zha, W. J., Zeng, X. N., \& Huang, M. (2016). Caffeic acid phenethyl ester alleviates asthma by regulating the airway microenvironment via the ROS-responsive MAPK/Akt pathway. Free Radical Biology and Medicine, 101, 163-175. 
Olczyk, P., Komosinska - Vassev, K., Wisowski, G., Mencner, L., Stojko, J., \& Kozma, E.M. (2014). Propolis modulates fibronectin expression in the matrix of thermal Injury. BioMed Research International, ID 748101, 1 -10.

Silici, S. (2008). Farklı botanik orijine sahip propolis örneklerinde biyolojik olarak aktif bileşiklerin belirlenmesi. Erciyes Üniversitesi Fen Bilimleri Enstitüsü Dergisi, 24(1-2), 120-128.

Silici, S. (2019). Honeybee products and apitherapy. Turkish Journal of Agriculture - Food Science and Technology,
7(9), 1249-1262.

Stangaciu, S. (2006). What is apitherapy? Retrieved from https://www.apitherapy.com.

Şirin, Y., Çakırı, H. E., Can, Z., Yıldız, O., \& Kolaylı, S. (2017). Bal Arısı Zehrinin Karakterizasyonunda Sds-Page Elektroforez Kullanılabilirliğinin Araştırıması. Uludag Bee Journal, 16(2), 49-56.

Zumla, A., \& Lulat, A. (1989). Honey--a remedy rediscovered. Journal of the Royal Society of Medicine, 82(7), 384-385. 
